\title{
Investigation of the Lifelong Learning Tendency of College Students
}

\author{
Hamit Aksoy ${ }^{1, *}$, Hasan Erbay ${ }^{2}$, Hakan Kör ${ }^{1}$, Melih Engin ${ }^{3}$ \\ ${ }^{1}$ Department of Computer Technologies, Sungurlu Vocational School, Hitit University, Turkey \\ ${ }^{2}$ Department of Computer Engineering, Faculty of Engineering, Kirkkale University, Turkey \\ ${ }^{3}$ Department of Management Information Systems, İnegöl Faculty of Business, Uludağ University, Turkey
}

Copyright $\odot 2017$ by authors, all rights reserved. Authors agree that this article remains permanently open access under the terms of the Creative Commons Attribution License 4.0 International License

\begin{abstract}
The concept of 'lifelong learning (LLL)' has emerged because of the necessity of renewing earlier and immemorial information in time. LLL is involved in a various kind of international foundations' works. European Union is perceived as more efficient in comparison with international companies in terms of lifelong learning practices. European Commission defines the lifelong learning as not only knowledge and aptitude, but also a beneficial opportunity in order to survive individual, social and economic life or in every single field of learning skills and activities. The important place of lifelong learning in the world is utilized to identify the tendency of exact learning levels. In this study, 'Lifelong Learning Tendency Scale' has been enforced as survey to students who studied in different departments for 2016-2017 Spring year. There were 148 vocational school students from 5 different departments. In this study, 4 sub-categories has been determined as motivation, perseverance, the absence of organizing learning and the absence of curious with the demographic information of participants. According to the scale results which was carried out on 5 different departments, it was received that while the highest score of lifelong learning tendency was considered as management, the lowest score was agreed as computer programming.
\end{abstract}

Keywords Lifelong Learning, Motivation, Organizing Learning, Perseverance, the Absence of Curious

\section{Introduction}

Individuals who acquired lifelong learning skill represents as impression as they could be successful in all probable fields. Lifelong learning requires the usage of active and constant information. People who can reach the information when one needs for the solution of problems and who could add new ones into it are described as individuals who have the lifelong learning skill (Polat and Odabaş, 2008). It is a quite significant situation for universities that have distance education to raise ones who can contemplate critically, solve a problem, make a decision independently and have lifelong learning skill (Göksan, et al., 2009).

Since Grundtvig utilized the concept of lifelong learning for the first time in his works, he is regarded as the founder of this notion. Then Comenius' perceptions constituted the backbone of this abstraction (Wain, 2000).

Nowadays, the notion of lifelong learning has been utilized in the national and international foundations' studies frequently. It was deducted that "Green Bulletin" as a project which aims to reduce the unemployment rates and to turn a constant vocational school organization in a systematic structure by a commission established in 1990s by EU. European Union that runs a "Through Learner Society" project has published a commission report which is named as "White Bulletin" intending to raise the awareness of lifelong learning (Akbaş and Özdemir, 2002).

Lifelong learning involves the vocational and technical education, the widespread ranges of including, during and excluding the service in terms of learning process. In other words, it could be appreciated as an advantageous opportunity which provides equality for individuals and also a process where there is no existence of time, place, age, socio-economic level or even education level (Günüç, et al., 2012).

The rapidly reasonable alterations, innovations and developments centered on information and communication technologies have brought about to define our current era as information era. One of the features of information era is to educate where, when and how to use information. In order to benefit from such qualified opportunity, individuals ought to accommodate these rapid innovations in technological and scientific developments; that is to say, they should be information literates (Köğce, et al., 2014). Therefore, it is required that information literates should advance their skills to access and to use knowledge in this complicated and complex world where producing and sharing information considerably.

In this study, lifelong learning tendency has been 
searched and studied demographically on 148 college students who were chosen as subjects. This investigation involves 5 vocational school students whose departments are different from each other. In order to reach exact responses, frequency, percentage, arithmetic mean, standard deviation, $\mathrm{t}$ test, one way variance analysis (Anova test) calculations have been realized. Consequently, existed learning skills are considered as valuable for education foundations and for educators in this time that reaching and learning information has an important place for individuals. In finding section, differentiation between scale scores and department based scale scores is emphasized in accordance with the demographic structure. And in result section, all evidences and findings have been gathered carefully and addressed to related foundations.

\section{Literature}

Network and information capacity have been increased with developing technology concept. Existed owned knowledge returns to the previous one after a while. Therefore, lifelong learning is regarded as one of the skills that are required for maintaining the coherence and congruence among the society in information era. Lifelong learning has been a notable notion for a while. This conception is included in various kind national and international foundations such as UNESCO, ILO, OECD, EU (Beycioğlu and Konan, 2008). UNESCO and EU have endeavored to draw attention to lifelong learning concept and declared the year of 1996 as lifelong learning year (Chien, 1996). Comparing with other international foundations, EU has been sought as much more efficient and active in implementation of lifelong learning systems (Lee, et al., 2008). EU interprets the notion of lifelong learning as activities that seek to improve the individuals' knowledge, skills, and talents in individual and social or vocational fields (European Commission, 2002). While Kulich (1982) described the state of lifelong learning as the distribution of education in one's lives, White (1982) defined this term as the preparation of one's lives to manage it carefully. And Lengrand (1979) explained as an education which is associated with whole life (Aspin and Chapman, 2000). As well as there is a theory that education involves every field of life; (Lindeman,1926; Yeaxlee,1929), the interest and attraction to lifelong learning has been increased lately by endeavoring much more planned and organized compared with previous one.

In order to evaluate and measure the attitude and the tendency towards lifelong learning, distinct range of scales was carried out such as teachers, students and academic staff. Inquiries investigating in this part were mostly incorporates studies, which were held in academic occasions. Coşkun and Demirel researched the lifelong learning tendency of college students in their studies. It was deducted that the average lifelong learning scales of students were low in this research which was eager to clarify whether university, class level and gender differs or not. In addition to this, the distinguished difference among university, class level and gender has been justified statistically (Coşkun and Demirel, 2012). The lifelong learning levels of 231 vocational school students have been examined carefully. The lifelong learning sufficiency scale which was belonging to Şahin (2010) has been operated as a sample scale. According to this research's results, the level of lifelong learning sufficiency was determined in satisfactory level. There was not any existence of reasonable differences between divisions. The higher the class level exists, the more the lifelong learning sufficiency has increased accurately (Şahin, 2010; Karakuş, 2013).

\section{Method}

In this section of research, choosing sample and research environment, collecting data tools, validity and credibility data, analysis tools and methods have been entailed precisely.

The Aim of Research: This research has been held in order to determine the distinctions between demographic structures of students and different related departments, in terms of emphasizing the lifelong learning tendencies.

Selection of Environment and Sample: Hitit University Sungurlu Vocational School students have constituted the base of the study. However, samples have selected randomly from students who responded the survey questions about lifelong learning tendency completely from 5 different accurate departments.

The Hypothesis of Research: What it is examined in terms of testing those relations is below;

H1. There is a strong association between demographic variance and lifelong learning scale scores.

H1.1. There is a rational connection between the gender of students and lifelong learning scale scores.

H1.2. There is a certain difference between lifelong learning scale scores with self-leadership and ages of students.

H1.3. There is a reasonable dissimilarity between the kind of high schools where students graduated and lifelong learning scale scores.

H1.4. There is an exact difference between the time which students have spent there and lifelong learning scale scores.

H2. There is a particular distinction between students' departments studying at and lifelong learning scale scores.

Collecting Data Tools: The lifelong learning scale score, which used in this project, was composed by Coşkun in 2009 as a sample of PhD. The validity and credibility of this measurement tool has realized on 2100 individuals as a mixture of 600 pilots and 1500 actual implementation. The term of scale consists of motivation, perseverance, the absence of organizing learning and the absence of curious (Coşkun, 2009). Since 148 students constitute the mass of this study as students from different departments, those who participated in research were selected from students of vocational schools randomly. 
Information of Validity and Credibility: Validity and factor analysis have accomplished of the scale. It was observed that all requirements were extremely valid and reliable for Cronbach's alpha value at 0.89 .

\section{Findings}

Basic statistics which are descriptive and analysis results were mentioned in this section.

Table 1. Descriptive statistics of demographic structure

\begin{tabular}{|c|c|c|c|}
\hline Variable & Category of Variable & $\mathrm{f}$ & Percent(\%) \\
\hline \multirow{3}{*}{ Gender } & Male & 58 & 39.2 \\
\cline { 2 - 4 } & Female & 90 & 60.8 \\
\hline \multirow{4}{*}{ Age } & $18-19$ & 27 & 18.2 \\
\cline { 2 - 4 } & $20-21$ & 91 & 61.5 \\
\cline { 2 - 4 } & $22+$ & 30 & 20.3 \\
\hline \multirow{4}{*}{ Department } & Computer Programming & 38 & 25.7 \\
\cline { 2 - 4 } & Child Development & 37 & 25.0 \\
\cline { 2 - 4 } & Foreign Trade & 23 & 15.5 \\
\cline { 2 - 4 } & Management & 20 & 13.5 \\
\cline { 2 - 4 } & Health Programmes & 30 & 20.3 \\
\hline \multirow{3}{*}{$\begin{array}{c}\text { Time Within the } \\
\text { University }\end{array}$} & 1 & 48 & 32.4 \\
\cline { 2 - 4 } & 2 & 86 & 58.1 \\
\cline { 2 - 4 } & $3++$ & 14 & 9.5 \\
\hline
\end{tabular}

Table 2 emphasizes the demographic structure which is affected by sample. $60.8 \%$ of this sample is female. Moreover, $61.5 \%$ of example includes age range of $20-21$ and $58.1 \%$ of subjects have been continuing the university over 2 years.

Table 2. T-test results according to gender

\begin{tabular}{|c|c|c|c|c|c|c|c|}
\hline Scale/size & Gender & $\mathrm{N}$ & $\mathrm{X}$ & $\mathrm{S}$ & $\mathrm{sd}$ & $\mathrm{t}$ & $\mathrm{p}$ \\
\hline \multirow{2}{*}{ Scale } & Male & 58 & 2.27 & 0.711 & 146 & 2.331 & 0.112 \\
\hline & Female & 90 & 4.56 & 0.796 & & & \\
\hline \multirow{2}{*}{ Motivation } & Male & 58 & 5.19 & 0.904 & 146 & 1.710 & 0.039 \\
\hline & Female & 90 & 5.39 & 0.559 & & & \\
\hline \multirow{2}{*}{ Perseverance } & Male & 58 & 4.61 & 0.829 & 146 & 1.702 & 0.704 \\
\hline & Female & 90 & 4.84 & 0.787 & & & \\
\hline \multirow{2}{*}{ Deficiency } & Male & 58 & 3.82 & 1.222 & 146 & 1.368 & 0.153 \\
\hline & Female & 90 & 4.13 & 1.400 & & & \\
\hline \multirow{2}{*}{ Absence of curious } & Male & 58 & 3.71 & 1.089 & 146 & 2.032 & 0.134 \\
\hline & Female & 90 & 4.11 & 1.244 & & & \\
\hline
\end{tabular}

The difference in accordance with gender presents only mean scores of sub-dimension motivation $(\mathrm{t}(146)=1.710$, $\mathrm{p}=0,039)$. Results of females are constantly higher $(\mathrm{X}=5,39)$. 
Table 3. Results of ANOVA considering departments

\begin{tabular}{|c|c|c|c|c|c|c|}
\hline & & Sum of Squares & $\mathrm{df}$ & Mean Square & $\mathrm{F}$ & Sig. \\
\hline \multirow{3}{*}{ Sum of Scale } & Between Groups & 3.012 & 4 & .753 & 1.260 & .289 \\
\hline & Within Groups & 85.469 & 143 & .598 & & \\
\hline & Total & 88.480 & 147 & & & \\
\hline \multirow{3}{*}{ Motivation } & Between Groups & 5.165 & 4 & 1.291 & 2.612 & .038 \\
\hline & Within Groups & 70.679 & 143 & .494 & & \\
\hline & Total & 75.844 & 147 & & & \\
\hline \multirow{3}{*}{ Perseverance } & Between Groups & 2.223 & 4 & .556 & .846 & .498 \\
\hline & Within Groups & 93.937 & 143 & .657 & & \\
\hline & Total & 96.159 & 147 & & & \\
\hline \multirow{3}{*}{ Deficiency } & Between Groups & 7.556 & 4 & 1.889 & 1.058 & .379 \\
\hline & Within Groups & 255.207 & 143 & 1.785 & & \\
\hline & Total & 262.763 & 147 & & & \\
\hline \multirow{3}{*}{ Absence of Curious } & Between Groups & 4.732 & 4 & 1.183 & .820 & .514 \\
\hline & Within Groups & 206.296 & 143 & 1.443 & & \\
\hline & Total & 211.028 & 147 & & & \\
\hline
\end{tabular}

When Levene test results have been clarified in order to observe the homogenous test results, it was recorded that variations were not distributed equally for sub-dimension motivation $(\mathrm{p}<0.05)$. In addition, it was noticed that there was not a clear distinction among lifelong learning scale scores of departments statistically.

Table 4. ANOVA results considering students' ages

\begin{tabular}{|c|c|c|c|c|c|c|}
\hline & & Sum of Squares & $\mathrm{df}$ & Mean Square & $\mathrm{F}$ & Sig. \\
\hline \multirow{3}{*}{ Sum of Scale } & Between Groups & .948 & 2 & .474 & .785 & .458 \\
\hline & Within Groups & 87.533 & 145 & .604 & & \\
\hline & Total & 88.480 & 147 & & & \\
\hline \multirow{3}{*}{ Motivation } & Between Groups & 1.696 & 2 & .848 & 1.658 & .194 \\
\hline & Within Groups & 74.148 & 145 & .511 & & \\
\hline & Total & 75.844 & 147 & & & \\
\hline \multirow{3}{*}{ Perseverance } & Between Groups & 1.103 & 2 & .551 & .841 & .433 \\
\hline & Within Groups & 95.056 & 145 & .656 & & \\
\hline & Total & 96.159 & 147 & & & \\
\hline \multirow{3}{*}{ Deficiency } & Between Groups & .751 & 2 & .376 & .208 & .813 \\
\hline & Within Groups & 262.012 & 145 & 1.807 & & \\
\hline & Total & 262.763 & 147 & & & \\
\hline \multirow{3}{*}{ Absence of Curious } & Between Groups & 2.835 & 2 & 1.417 & .987 & .375 \\
\hline & Within Groups & 208.193 & 145 & 1.436 & & \\
\hline & Total & 211.028 & 147 & & & \\
\hline
\end{tabular}

There was no reasonable difference between ages of students and lifelong tendency scale scores statistically. 
Table 5. ANOVA results considering time which students spend in schools.

\begin{tabular}{|c|c|c|c|c|c|c|}
\hline & & Sum of Squares & $\mathrm{df}$ & Mean Square & $\mathrm{F}$ & Sig. \\
\hline \multirow{3}{*}{ Sum of Scale } & Between Groups & .695 & 2 & .347 & .574 & .565 \\
\hline & Within Groups & 87.786 & 145 & .605 & & \\
\hline & Total & 88.480 & 147 & & & \\
\hline \multirow{3}{*}{ Motivation } & Between Groups & .231 & 2 & .115 & .221 & .802 \\
\hline & Within Groups & 75.613 & 145 & .521 & & \\
\hline & Total & 75.844 & 147 & & & \\
\hline \multirow{3}{*}{ Perseverance } & Between Groups & .674 & 2 & .337 & .511 & .601 \\
\hline & Within Groups & 95.486 & 145 & .659 & & \\
\hline & Total & 96.159 & 147 & & & \\
\hline \multirow{3}{*}{ Deficiency } & Between Groups & .066 & 2 & .033 & .018 & .982 \\
\hline & Within Groups & 262.697 & 145 & 1.812 & & \\
\hline & Total & 262.763 & 147 & & & \\
\hline \multirow{3}{*}{ Absence of Curious } & Between Groups & 3.038 & 2 & 1.519 & 1.059 & .350 \\
\hline & Within Groups & 207.990 & 145 & 1.434 & & \\
\hline & Total & 211.028 & 147 & & & \\
\hline
\end{tabular}

It was justified that this test did not culminate in with an enormous difference between time (year) which students spend in schools and lifelong tendency scale scores statistically.

Table 6. ANOVA results considering kinds of high schools where students graduated

\begin{tabular}{|c|c|c|c|c|c|c|}
\hline & & Sum of Squares & $\mathrm{df}$ & Mean Square & $\mathrm{F}$ & Sig. \\
\hline \multirow{3}{*}{ Sum of Scale } & Between Groups & .307 & 2 & .154 & .253 & .777 \\
\hline & Within Groups & 88.173 & 145 & .608 & & \\
\hline & Total & 88.480 & 147 & & & \\
\hline \multirow{3}{*}{ Motivation } & Between Groups & .477 & 2 & .238 & .459 & .633 \\
\hline & Within Groups & 75.367 & 145 & .520 & & \\
\hline & Total & 75.844 & 147 & & & \\
\hline \multirow{3}{*}{ Perseverance } & Between Groups & .688 & 2 & .344 & .523 & .594 \\
\hline & Within Groups & 95.471 & 145 & .658 & & \\
\hline & Total & 96.159 & 147 & & & \\
\hline \multirow{3}{*}{ Deficiency } & Between Groups & 1.172 & 2 & .586 & .325 & .723 \\
\hline & Within Groups & 261.590 & 145 & 1.804 & & \\
\hline & Total & 262.763 & 147 & & & \\
\hline \multirow{3}{*}{ Absence of Curious } & Between Groups & 2.211 & 2 & 1.105 & .768 & .466 \\
\hline & Within Groups & 208.817 & 145 & 1.440 & & \\
\hline & Total & 211.028 & 147 & & & \\
\hline
\end{tabular}

It was noted that there was not any existence of marked dissimilarity between varieties of high schools where students graduated and lifelong tendency scale scores statistically.

\section{Conclusion, Discussion and Suggestions}

"The term of lifelong learning could be defined as it enables society to update their knowledge, wisdom and skills, which is required to survive. Moreover, it supports individuals in order to acknowledge fluxional innovations in time and to broaden their horizons in terms of individual, vocational and intellectual levels of those" (Akkoyunlu,
2008).

In an accurate research which was held by Coşkun and Demirel, it was aimed to determine the lifelong learning tendency of people considerably. In the research, it was emphasized that average scores which were acquired from the scale is lower than average scale scores. "In this manner, it was observed that not only students were not willing to participate a various activities centered around lifelong learning, but also they had a problem with organizing 
lifelong learning activities definitely. In addition, it was recorded that the concept of curious which is an essential determinant of lifelong learning has not been inside of students considerably (Coşkun and Demirel, 2012).

In another research which examines the lifelong learning sufficiency of vocational school students, it was mentioned that the situation of students was found in a great position. "From the perspective of sub-dimension of scale, communication sufficiency in native language, social and citizenship sufficiency, initiative and entrepreneurship satisfactoriness, cultural awareness and expression satisfactoriness, having learning ability, digital adequacy, mathematical and scientific adequacy were observed in a good level" (Karakuş, 2013). Also in such a study that students were selected from vocational schools by Arsal (2011), the lifelong learning tendency of students (nominees for being teachers) was determined and there was no exact or significant difference between them.

When the results of this research were analyzed, the lifelong learning tendency scale scores of college students were regarded as incredibly at high level. With reference to this information, the lifelong learning skills of students were quite fine. In the study, variables were compared in accordance with gender, age, graduated high school and time that students have spent in schools. There was a relationship between only gender and lifelong learning statistically based on these variables. Moreover, regarding to this relationship, it was asserted that comparing with men, women has higher levels in terms of lifelong learning scale. Nevertheless, there was no exact difference among departments of students and their lifelong learning scale scores considerably.

It was emphasized that lifelong learning skills are able to alter and therefore, giving importance to a range of strategies in Parkinson. These strategies are; communication expectations, burden of learning responsibilities of students, maintaining the motivation of students, providing an opportunity like learning outside of school as well and teaching students how to learn. Also in higher education, by utilizing such strategies that providing students to manage their own education process, using active learning methods in education, ensuring that students could able to solve their own problems immediately, encouraging students to make self-assessment can have beneficial advantageous for universities. Considering all these activities in the education life, not only it prepares students to life as lifelong learners, but also it gives an opportunity of being a better learner during education life (Parkinson, 1999).

This research is restricted with the students of Hitit University Sungurlu Vocational Higher Education School. Nonetheless, it was considered that there would be more comprehensive, widespread and intriguing results if there was a bigger and wider environment to observe.

\section{REFERENCES}

[1] Akbaş, O. ve Özdemir, S.M. (2002). Avrupa Birliğinde Yaşam Boyu Öğrenme. Milli Eğitim Dergisi (156), 112-126.

[2] Akkoyunlu, B. (2008, May). Information literate and lifelong learning. In 8th International Educational Technology Conference (IETC2008) (6-9).

[3] Arsal, Z. (2011). Lifelong Learning Tendencies of the Prospective Teachers İn the Bologna Process in Turkey. ATTE Annual Conference 2011: Teachers' Life-cycle from Initial Teacher Education to Experienced Professional, Latvia University, Riga 496-509.

[4] Aspin, N. D. \& Chapman, J. D. (2000). Lifelong Learnıng: Concepts and Conception. İnternational Journal of Lifelong Education, Vol: 19 No.1, 2-19.

[5] Avrupa Komisyonu (2002). European report on quality indicators of lifelong learning. Fifteen quality indicators. European Commission report, Directorate-General for Education and Culture, Brussels.16.10.2012 tarihinde ulaşılmıştır.

[6] Beycioğlu, K. ve Konan, N. (2008). Yaşam Boyu Ögrenme Ve Avrupa Eğitim Politikaları. Electronic Journal of

[7] Chien, M. "Power and knowledge in education: A critical exploration of lifelong learning". Unpublished doctoral dissertation, Northern Illinois University (1996).

[8] Coşkun Diker, Yelkin (2009). "Üniversite öğrencilerinin yaşamboyu öğrenme ĕgilimlerinin bazl değişkenler açısından incelenmesi". Hacettepe Üniversitesi, Sosyal Bilimler Enstitüsü, Eğitim Bilimleri Bölümü, Eğitim Programları ve Öğretim Anabilim dalı. Yayınlanmamış doktora tezi. Ankara.

[9] Coşkun, Y., D. Ve Demirel M. (2012). Üniversite Ögrencilerinin Yaşamboyu Öğrenme Eğilimleri, Hacettepe Üniversitesi Eğitim Fakültesi Dergisi, 42, 108-120.

[10] Göksan, T. S., Uzundurukan, S., Keskin, S. N., (2009). Yaşam Boyu Ögrenme ve Avrupa Birliği'nin Yaşam Boyu Öğrenme Programlart, 1. İnșaat Mühendisliği Eğitimi Sempozyumu, Antalya, 143-151.

[11] Günüç, S., Odabaşı, H. F. \& Kuzu, A. (2012). Yaşam Boyu Öğrenmeyi Etkileyen Faktörler. Gaziantep Üniversitesi Sosyal Bilimler Dergisi, 11(2): 309 -325.

[12] Karakuş, C. (2013). Meslek yüksekokulu öğrencilerinin yaşam boyu öğrenme yeterlikleri. Eğitim ve Öğretim Araştırmaları Dergisi, 2(3), 26-35.

[13] Köğce, D., Özpınar,İ, Mandacı Şahin, S., Aydoğan Yenmez, A. (2014). Instructors' Views on Standards for the 21th Century Learners and Lifelong Learning. Dicle Üniversitesi Ziya Gökalp Eğitim Fakültesi Dergisi, 22 (2014) 185-213.

[14] Kulich, Jindra. "Lifelong education and the universities: A Canadian perspective". International Journal of Lifelong Education 1.2 (1982): 123-142.

[15] Lengrand, P. (1979). Prospects of lifelong education. AJ Cropley Ed, 28-35.

[16] Lindeman, E. C. (1926). Andragogik: The method of teaching adults. Workers' Education, 4(3), 8.

[17] Parkinson, A. (1999, November). Developing the attribute of 
lifelong learning. In Frontiers in Education Conference, 1999. FIE'99. 29th Annual (Vol. 1, pp. 11A1-16). IEEE.

[18] Polat, C., Odabaş, H., (2008). Bilgi Toplumunda Yaşam Boyu Öğrenmenin Anahtarl: Bilgi Okuryazarlığ Küreselleşme, Demokratikleşme ve Türkiye Uluslararası Sempozyumu, Akdeniz Üniversitesi, Antalya, 143-151.

[19] Social Sciences, C.7, S.24 (369-382).

[20] Şahin, M., Akbaşl1, S. ve Yanpar Yelken T. (2010). Key
Competences for Lifelong Learning: The Case Of Prospective Teachers, Educational Research And Review, Vol. 5 (10), s. 545-556.

[21] Wain, K. (2000). The learning society: postmodern politics. International Journal of Lifelong Education, 19 (1), 36-53.

[22] White, J. P. 1982. The Aims of Education Re-Stated, London: Routledge and Kegan Paul.

[23] Yeaxlee, B. A. (1929). Lifelong Education, London: Cassell. 